Japan. J. Med. Sci. Biol., 39, 139-149, 1986.

\title{
ANTI-INFLAMMATORY ACTIVITY OF 6MFA, A COMPOUND OBTAINED FROM FUNGUS ASPERGILLUS OCHRACEUS
}

\author{
Suresh R. NAIK, Vinay K. DESHMUKH and PalghatH. RAMAN \\ Pharmacology and Toxicology Section, Research and Development Division, \\ Hindustan Antibiotics Ltd., Pimpri, Pune 411 018, India
}

(Received February 14, 1986. Accepted July 14, 1986)

SUMMARY: 6MFA, an interferon-inducing substance obtained from fungus, Aspergillus ochraceus, has shown anti-inflammatory activity both in acute and chronic animal models of inflammation. It was found that 6MFA was equally effective in inhibiting both exudative as well as granulative phase of inflammation. The compound suppressed also cellular migration during inflammatory process and potentiated significantly the anti-inflammatory activity of indomethacin. The compound was devoid of analgesic or antipyretic activity.

The probable mechanism of action of this compound is not fully understood. However, the possibility of triggering the induction of endogenous antiinflammatory substance(s) along with interferon(s), or interaction of induced interferon(s) directly or indirectly with the prostaglandin system has been attributed.

\section{INTRODUC'TION}

6MFA (see a footnote on page 146), a new microbial compound containing polysaccharide, protein and nucleic acid (double-strand RNA) obtained from fungus, Aspergillus ochraceus, ATCC $28706(1,2)$, has been shown to possess antiJapanese-encephalitis activity in a murine model $(3,4)$.

Interferon induction has been shown to be the basis of anti-viral resistance activity of 6MFA (3). Tests have also indicated that immune response of the vertebrate host plays a significant role in concert with interferon response to achieve the mouse protection $(5,6)$.

Interferon-inducing agents like ploy $\mathrm{I} / \mathrm{C}$, tilorone and statolon have shown to elicit significant anti-inflammatory activity (7-11). In addition, rheumatoid 
arthritic patients receiving interferon therapy showed significant improvement in grip-strength and motility of joints (12).

With these background information, we decided to investigate the effect of 6MFA on different animal models of inflammation and also attempted to explain possible mode of action of this compound.

\section{MATERIALS AND METHODS}

Male albino rats of Hindustan Antibiotic (HA) strain weighing 120-150 g were used throughout the study. The rats were kept on a light-dark cycle $(10 \mathrm{hr}$ light and $14 \mathrm{hr}$ dark) and maintained on HA diet and water ad libitum in our animal quarters.

Drug solutions and treatment schedule: 6MFA Lot 7-84 (which has shown $100 \%$ and $70 \%$ anti-viral activity in Japanese encephalitis (JE) and Semliki Forest virus (SFV) mouse models respectively) was used for all the experimental studies and solutions were prepared in distilled water just before the experiment. Indomethacin was obtained from Merck Sharp and Dhome, Bombay, and prepared as a suspension in a $0.5 \%(\mathrm{w} / \mathrm{v})$ carboxymethyl cellulose solution. The time interval between 6MFA administration and the injection of various inflammatory agents, viz., carrageenin, albumin, Freund's adjuvant and UV erythema, was kept $17 \mathrm{hr}$, because at this interval 6MFA elicited maximum effect. However, in cotton pellet granuloma and granuloma pouch experiments, 6MFA was administered twice at an interval of 4 days to minimize hyporesponsiveness of the second dose with respect to interferon induction.

Carrageenin - induced edema: Carrageenin edema was induced by injecting subcutaneously carrageenin into the plantar region of the hind-paw of rats according to the method of Winter et al (13).

A group of rats were treated with $6 \mathrm{MFA}$ (10 mg/kg intraperitoneally) $17 \mathrm{hr}$ prior to indomethacin and carrageenin was injected $1 \mathrm{hr}$ after indomethacin treatment. $\mathrm{ED}_{50}$ of indomethacin with and without $6 \mathrm{MFA}$ treatment for carrageenin edema inhibition was calculated.

Albumin - induced edema: Albumin edema was produced by injecting subcutaneously $0.1 \mathrm{ml}$ of $2 \%$ (w/v) bovine albumin (Sigma Chemicals Co., St. Louis, MO), prepared in normal saline, into the plantar region of the hind-paw of rats.

Freund's adjuvant edema [18 hr arthritis test - Sofia et al (14)]: Rats were injected subcutaneously $0.1 \mathrm{ml}$ of complete Freund's adjuvant (Difco Laboratories, Detroit, MI) into the plantar region of the right hind-paw.

Ultraviolet - induced erythema: Albino guinea pigs weighing 250-300 g were prepared for UV exposure as described by Winder (15). Three circular areas (6 mm 
diameter) of the right flank were exposed to UV radiation for $30 \mathrm{sec}$ from a quartz lamp. Following UV exposure the intensity of erythema at different time intervals was visually graded by a trained observer unaware of the treatment schedule using an arbitrary scale $0-3$ as follows:

0 - No evident erythema.

1 - A mild reaction, pale pink color.

2 - An intermediate response between 1 and 3 .

3 - An intense reaction, deep reddish pink in color.

The maximum score for a three point exposure in an animal was 9 .

Drugs, 6MFA (100 mg/kg intraperitoneally) and indomethacin $(10 \mathrm{mg} / \mathrm{kg}$ orally) were administered 17 and $1 \mathrm{hr}$, respectively, prior to UV exposure. Six guinea pigs were used for each dose level.

Cotton pellet granuloma: Cotton pellet granuloma was induced in rats according to the method of Winter and Portar (16). Four sterilized cotton pellets each weighing $10 \mathrm{mg}$ were implanted two on either side of the ventral region. On the 9th day, pellets were removed together with granuloma and dried at $70 \mathrm{C}$ for 6 $\mathrm{hr}$ and weighed. The increase in dry weight was taken as a measure of granuloma formation.

6 MFA ( $100 \mathrm{mg} / \mathrm{kg}$ intraperitoneally) was administered twice at an interval of 4 days, commencing a day prior to cotton pellet implantation. Indomethacin (3 $\mathrm{mg} / \mathrm{kg}$ orally) was administered daily for 8 days from the day of cotton pellet implantation. The granuloma inhibition with the drug treatment was calculated by comparing with granuloma formation in the untreated control group.

Granuloma pouch: A granuloma pouch was produced on the shaven back (dorsal side) of the rat by injecting subcutaneously $25 \mathrm{ml}$ of air. Croton oil $0.5 \mathrm{ml}$ of $0.5 \%(\mathrm{v} / \mathrm{v})$ prepared in corn oil was injected into this pouch (17). On the 10th day, rats were sacrificed by ether anesthesia; exudates from the pouches were harvested and volumes were recorded with the help of a syringe. Thereafter, the pouches were carefully dissected and made free from extraneous tissue. The dry weights of the pouches were recorded after drying in an oven at $70 \mathrm{C}$ for $6 \mathrm{hr}$ or till a constant weights was obtained.

To see the effect of 6MFA on cellular response (the basic inflammatory response) of the croton oil-induced granuloma pouch, the differential cell counts in the exudate of intrapouch-treated rats were made on stained smears using counting chambers. The cell counts were made with respect to total volume of the exudate.

Statistical analysis: Results were expressed as mean \pm SEM. The effect of various pretreatment on base-line parameters was assessed by student ' $t$ ' test (two tailed) and $P$-values greater than 0.05 were considered as not significant. 
$\mathrm{ED}_{50}$ values of indomethacin and $6 \mathrm{MFA}$, with $95 \%$ confidence limits for the inhibition of different types of edemas were calculated by the method of Litchfield and Wilcoxon (18).

\section{RESULTS}

6MFA treatment inhibited significantly carrageenin, albumin and Freund's adjuvant-induced edemas. The $\mathrm{ED}_{50}$ values of $6 \mathrm{MFA}$ and indomethacin in different edemas are shown in Table $I$. The $E_{50}$ values of $6 \mathrm{MFA}$ and indomethacin were different in different edemas and their potencies in these inflammatory models were of the order, Carrageenin $>$ albumin $>$ Freund's adjuvant.

Table I. ED ED $_{50}$ of 6 FA in different experimentally induced hind-paw edema in rats

\begin{tabular}{lcc}
\hline \multirow{2}{*}{$\begin{array}{l}\text { Type of } \\
\text { inflammation }\end{array}$} & $\begin{array}{c}\text { EMFA } \\
\text { (ip) }\end{array}$ & $\begin{array}{c}\text { Indomethacin } \\
\text { (per os) }\end{array}$ \\
\cline { 2 - 3 } & $22.0(16.0-31.0)$ & $2.6(1.7-3.9)$ \\
Carrageenin edema & $48.0(36.0-63.0)$ & $7.2(5.6-9.4)$ \\
Albumin edema & $62.0(24.8-130.6)$ & $11.2(8.6-14.6)$ \\
$\begin{array}{l}\text { Freund's adjuvant } \\
\text { edema }\end{array}$ & & \\
\hline
\end{tabular}

6MFA was administered intraperitoneally at different doses $17 \mathrm{hr}$ prior to carrageenin and albumin injection. Paw volumes were measured on a plethysmographic apparatus before and $3 \mathrm{hr}$ after carrageenin or albumin injection. Mean edema volume was determined and inhibition was calculated with respect to its vehicle-treated group. In case of Freund's adjuvant edema, 6MFA was administered intraperitoneally $1 \mathrm{hr}$ prior to Freund's adjuvant injection and paw volumes were measured before and 17 $\mathrm{hr}$ after Freund's adjuvant injection. Indomethacin was administered orally $1 \mathrm{hr}$ prior to carrageenin, albumin or Freund's adjuvant injection. 
It was also found that pretreatment with $6 \mathrm{MFA}(10 \mathrm{mg} / \mathrm{kg}$ intraperitoneally) at a noneffective dose (less than 15\% edema inhibition) potentiated the antiinflammatory (AI) activity of indomethacin significantly. $\mathrm{ED}_{50}$ for $6 \mathrm{MFA}+$ indomethacin was $1.2(0.9-1.6) \mathrm{mg} / \mathrm{kg}$ and for indomethacin alone was $2.6(1.7-3.9)$ $\mathrm{mg} / \mathrm{kg}$.

The time course development of UV erythema in guinea pigs indicate that within $15 \mathrm{~min}$ after UV exposure, erythema appeared in some animals and by 30 min all the animals developed distinct lesions, pale pink in color. The intensity of the reaction rapidly increased reaching maximum by $5 \mathrm{hr}$. At the maximum, the lesions appeared deep reddish-pink in color (Fig. 1).

The erythema persisted with more or less of the same intensity for about $6 \mathrm{hr}$ when a slow subsidence began. The reaction was noticeable even at $24 \mathrm{hr}$ though the lesions were then more dusty in color.

Treatment with 6MFA delayed the onset and development of UV erythema (Fig. 1). The intensity of erythema response was comparatively less in 6MFA and

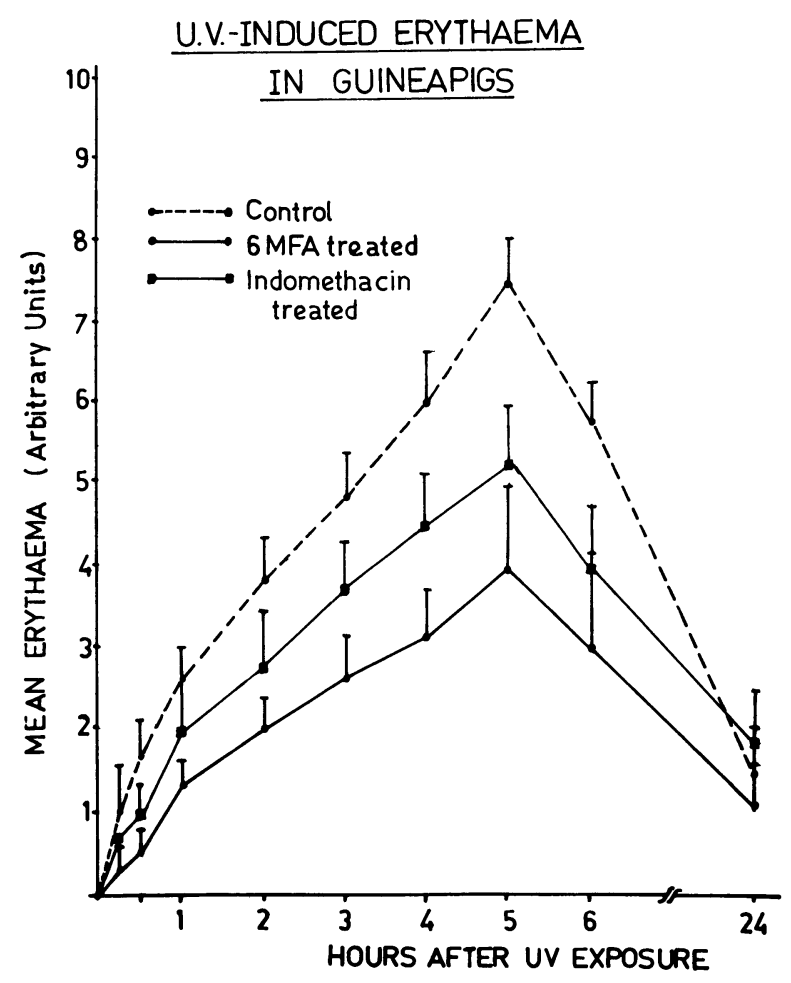

Fig. 1. Each point represents the mean observations of six guinea pigs; the vertical bars indicate the standard deviation of mean. 
Table II. Effect of 6MFA on Croton oil-induced granuloma in rats

\begin{tabular}{lccc}
\hline $\begin{array}{l}\text { Treatment } \\
\text { and dose }\end{array}$ & Route & $\begin{array}{c}\text { Exudate volume (ml) } \\
\text { Mean } \pm \text { SEM }\end{array}$ & $\begin{array}{c}\text { Granulation tissue(g) } \\
\text { Mean } \pm \text { SEM }\end{array}$ \\
\hline Control & - & $7.3 \pm 0.7$ & $1.3 \pm 0.24$ \\
6MFA & ip & $5.3 \pm 0.3$ & $0.8 \pm 0.1$ \\
$(100 \mathrm{mg} / \mathrm{kg})$ & & $\mathrm{P} 0.05$ & $\mathrm{P} 0.03$ \\
$\begin{array}{l}\text { Indomethacin } \\
(3 \mathrm{mg} / \mathrm{kg})\end{array}$ & po & $6.1 \pm 0.8$ & $1.0 \pm 0.3$ \\
$\begin{array}{l}6 \mathrm{MFA} \\
(2 \mathrm{mg})\end{array}$ & & $\mathrm{N} . \mathrm{S}$. & $\mathrm{N} . \mathrm{S}$. \\
Indomethacin & Intra- & $3.5 \pm 0.25$ & $0.4 \pm 0.1$ \\
$(0.5 \mathrm{mg})$ & Intra- & $\mathrm{P}<0.001$ & $\mathrm{P}<0.001$ \\
& pouch & $5.0 \pm 0.8$ & $0.7 \pm 0.4$ \\
& & $\mathrm{P}<0.03$ & $\mathrm{P}<0.01$ \\
\hline
\end{tabular}

A group of rats with granuloma pouch received 6 MFA $(100 \mathrm{mg} / \mathrm{kg})$ by the ip route twice in the 8 days' period at an interval of 4 days. Another group of granuloma pouch rats were received $6 \mathrm{MFA}(2 \mathrm{mg} / \mathrm{rat})$ via the intrapouch rouute once only.

Similarly, indomethacin $(3 \mathrm{mg} / \mathrm{kg})$ was administered orally daily for 8 days to a group of rats with the granuloma pouch, and another group received ( 0.5 $\mathrm{mg} / \mathrm{rat}$ ) via intrapouch once only. The rats from all groups were sacrificed on the 9 th day after the induction of the pouch and effects of drugs were compared with the untreated control group. Each consisted of 8-10 rats.

indomethacin-treated guinea pigs than the untreated control for the observation period. However, delay in erythema development was significantly greater in 6MFA-treated animals than in indomethacin-treated animals.

In cotton pellet granuloma experiments, treatment with 6 MFA $(100 \mathrm{mg} / \mathrm{kg}$ intraperitoneally, twice in 8 days) and indomethacin (daily $3 \mathrm{mg} / \mathrm{kg}$ orally for 7 days) elicited $25 \%$ and $50 \%$ inhibitions, respectively, in granular tissue formation. 


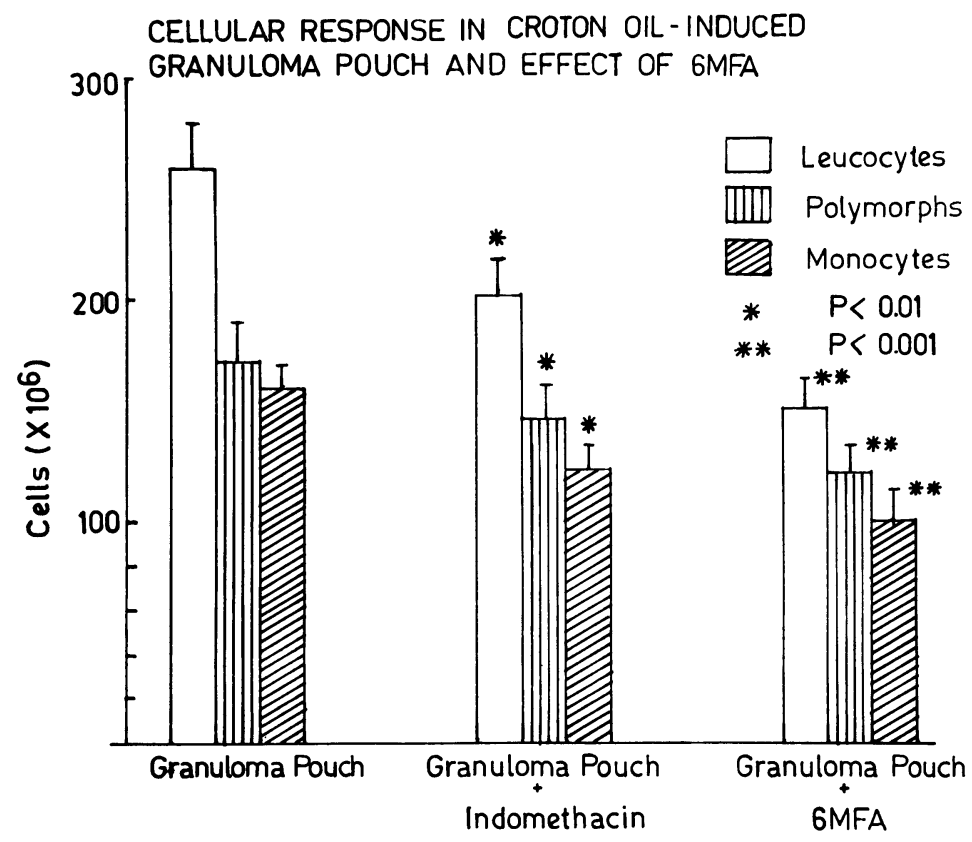

Fig. 2. Each point represents 6-8 observations, the vertical bars indicate the standard error of mean, ${ }^{*} \mathrm{P}<0.05,{ }^{* *} \mathrm{P}<0.01$.

In granuloma pouch experiments, treatment with 6MFA both by the intraperitoneal and intrapouch routes showed marked inhibition in exudate and granular tissue formation (Table II). Administration by the intrapouch route showed greater effect than by the ip route. Indomethacin treatment showed significant effect on exudate and granular tissue formation only by the intrapouch route (Table II). Increased cell counts, viz., leukocytes, polymorphs and monocytes, in the exudate of the granuloma pouch were decreased significantly with the treatment with both 6MFA and indomethacin (Fig. 2). The decrement in cell counts in the 6MFA-treated group was more marked than that in the indomethacin-treated group.

Therapeutic index of 6MFA and indomethacin in different edemas indicate that 6MFA has a large therapeutic index than does indomethacin (Table III).

6MFA did not elicit any analgesic activity in mice (Swiss strain) when tested by the tail-clip, shock and thermal methods. 6MFA also failed to show any antipyretic activity in yeast-induced pyrexia rats. 
Table III. Therapeutic index of 6MFA in carrageenin, albumin and adjuvant arthritis (18 $\mathrm{hr}$ arthritis test)

\begin{tabular}{lccc}
\hline \multirow{2}{*}{ Drug } & \multicolumn{3}{c}{ Therapeutic index $=\frac{\mathrm{LD}_{50}}{\mathrm{ED}_{50}}$} \\
\cline { 2 - 4 } & $\begin{array}{c}\text { Carrageenin } \\
\text { edema }\end{array}$ & $\begin{array}{c}\text { Albumin } \\
\text { edema }\end{array}$ & $\begin{array}{c}\text { Freund's adjuvant } \\
\text { arthritis }\end{array}$ \\
\hline 6MFA & 40.5 & 18.6 & 14.4 \\
$\begin{array}{l}\text { Indo- } \\
\text { methacin }\end{array}$ & 18.0 & 13.8 & 8.4 \\
\hline
\end{tabular}

The $\mathrm{LD}_{50}$ of 6MFA was $890(692-1,157) \mathrm{mg} / \mathrm{kg}$ (ip) and indomethacin data presented here are our own unpublished laboratory findings.

\section{DISCUSSION}

6MFA* has been shown to possess an ability to induce interferon in rats $(3,19)$. Reviewing past literature, we found that interferon inducers, viz., poly $\mathrm{I} / \mathrm{C}$,

\footnotetext{
*Physico-chemical information on 6MFA

\begin{tabular}{lc}
\hline Chemical composition of 6MFA & $\%(\mathrm{w} / \mathrm{w})$ \\
\hline Components: & \\
Polysaccharide & $90-92$ \\
Virus like particle (Nucleo protein) & $8-10$ \\
ds RNA 1 ) & 0.27 to 0.34 \\
RNA $^{2}$ & 6.0 to 7.0 \\
\hline
\end{tabular}

1): Expressed as \% of 6MFA.

2): \% of virus like particle (nucleo protein), five molecular fragments ( 0.5 to $1.5 \times 10^{6}$ daltons). The polysaccharide component is inert but appears to contribute to the stability of 6MFA. The thermal melting point of ds RNA is $91.6 \mathrm{C}$ in sodium citrate saline (Dr. B.M. Gupta's personal communication).
} 
statolon and tilorone, inhibited experimentally induced inflammation in animals $(7,8,11,20)$. The AI activity of interferon inducers was found to be not mediated through glucocorticoids liberation or prostaglandin synthetase inhibition $(7,8,20)$. Furthermore, it was observed in the clinics that patients receiving interferon therapy showed a significant improvement in grip strength and motility of joints (12).

In the present study, it was observed that $6 \mathrm{MFA}$ showed a significant antiinflammatory activity both in acute and subchronic animal models of inflammation. Moreover, $6 \mathrm{MFA}$ was equally effective in inhibiting both exudative and granu-lative phases of inflammatory processes. Furthermore, 6MFA treatment elicited a marked suppression of leukocyte migration to the site of inflammation.

Even today, the mode(s) of action of anti-inflammatory drugs in inflammation remains obscure or at least controversial (21). However, available reports indicate that non-steroidal anti-inflammatory drugs interfere with variety of cell functions e.g., generation and/or action on prostaglandin or other mediators (2225). It was observed in our present study that $6 \mathrm{MFA}$ not only potentiated AI activity of indomethacin in carrageenin edema but also suppressed significantly cellular migration into the exudate of the granuloma pouch. Furthermore, Singh et al. (26), have reported that $6 \mathrm{MFA}$ treatment potentiated significantly the indomethacin toxicity in mice. These observations along with our present findings indicate that 6MFA by itself or induced interferons may affect the prostaglandin system either directly or indirectly and may elicit AI activity. Alternatively, it is possible that 6MFA like tilorone may activate endogenous AI substances from plasma (20).

However, it would be important to determine - firstly, whether interferon induces or activates the production of natural endogenous AI substances such as orgotenin, ceruloplasmin, etc., during the course of interferon induction? Secondly, whether the intermediate products formed during interferon induction are triggering anti-inflammatory processes? Thirdly, whether AI activity of 6MFA could be attributed to the combined effect of endogenous anti-inflammatory substances and interferons?

\section{ACKNOWLEDGEMENTS}

Authors are thankful to General Manager, Research and Development, for rendering all the facilities to complete this work. We are indebted to Mr. S. L. 
Thorat for his technical assistance and acknowledge the Department of Science and Technology for their financial assistance.

\section{REFERENCES}

1. Maheshwari, R. K. and Gupta, B. M. (1973a): J. Antibiotics, 26, 320-327.

2. Maheshwari, R. K. and Gupta, B. M. (1973b): J. Antibiotics, 26, 328-334.

3. Maheshwari, R. K., Hussain, M. M. and Gupta, B. M. (1977): Acta Virol., 21, 63-70.

4. Maheshwari, R. K., Gupta, B. M., Ghosh, S. N. and Gupta, N. P. (1978): Ind. J. Med. Res., 67, 183-189.

5. Maheshwari, R. K. and Gupta, B. M. (1973c): J. Antibiotics, 26, 335-338.

6. Singh, V. K., George, C. X., Singh, N., Agarwal, S. S. and Gupta, B. M. (1983): Planta Medica, 47, 234-236.

7. Kapusta, M. A. and Mendeson, J. (1967): Proc. Soc. Exptl. Biol. Med., 126, 496-499.

8. Koltai, M. and Mecs, E. (1973): Nature, 242,, 525-526.

9. Megel, H., Raychaudhari, A., Goldstein, S., Kinsolving, C. R., Shemano, I. and Michael, J. G. (1974): Proc. Soc. Exptl. Biol. Med., 145, 513-518.

10. Megel, H., Raychaudhari, A., Shemano, I., Beaver, T. H. and Thomas, C. C. (1975): Proc. Soc. Exptl. Biol. Med., 149, 89-93.

11. Pearson, C. M. and Chang, Y. H. (1977): Adjuvant Arthritis: Immune responses and effect of tilorone or interferon in partially suppressing the disease: Prospect, Inflammation, Proc. Int. Med., III, 131-145. [eds.] D. A. Willoughloy, J. P. Giroud, and G. P. Velo, Univ. Park Press, Baltimore.

12. Kajander, A. K., Essen, R. V., Isomaki, H. and Cantell, K. (1979): Lancet, i, 984-985.

13. Winter, C. A., Risleyand, E. A. and Nuss, G. W. (1962): Proc. Soc. Exptl. Biol. Med., 111, 544-554.

14. Sofia, R. D., Knoblock, L. C. and Vassar, H. B. (1975): J. Pharmacol. Expt. Therap., 193, 918-931.

15. Winder, V. C.,Wax, J., Burr, V., Been, M. and Resiers, C. E. (1958): Arch. Int. Pharmacodyn., 116, 261-272.

16. Winter, C. A. and Portar, C. C. (1957): J. Amer. Pharm. Sci., 46, 515.

17. Selye, H. (1953): Proc. Soc. Exptl. Biol. Med., 82, 328-332.

18. Litchfield, J. T. and Wilcoxon, F. (1949): J. Pharmacol. Exptl. Therap., 96, 99-113.

19. Ghosh, S. N., Goverdhan, K. K., Cecilia, D., Chellian, S., Kedarnath, N. and Gupta, B. M. (1984): Ind. J. Med.Res., 79, 705-708.

20. Ford-Hutchinson, Bolans, J. P. and Walker, J. R. (1976): J. Pharm. Pharmacol., 28, 790.

21. Paulus, H. E. and Whitehouse, M. W. (1973): Ann. Rev. Pharmacol., 13, 107124. 
22. Spector, W. G. and Willoughby, D. A. (1968): The Pharmacology of inflammation. Grune and Straton, New York.

23. Vane, J. R. (1971): Nature, New Biol., 231, 232-235.

24. Ignarro, L. J. and Colombo, C. (1972): Nature, New Biol., 239, 155-157.

25. Ferreira, S. H. and Vane, J. R. (1974): Ann. Rev. Pharmacol., 14, 57-73.

26. Singh, V. K., George, C. X. and Gupta, B. M. (1981): Ind. J. Med. Res., 74, 617-620. 